\title{
Social Aspects of Water Scarcity and Drought
}

\section{Hohenthal, Johanna}

CRC press

2017

Hohenthal , J \& Minoia , P 2017 , Social Aspects of Water Scarcity and Drought . in S

Eslamian \& F A Eslamian (eds), Handbook of Drought and Water Scarcity : Principles of

Drought and Water Scarcity . CRC press , Boca Raton , pp. 607-626 . https://doi.org/10.1201/9781315404219-32

http://hdl.handle.net/10138/217123

https://doi.org/10.1201/9781315404219-32

acceptedVersion

Downloaded from Helda, University of Helsinki institutional repository.

This is an electronic reprint of the original article.

This reprint may differ from the original in pagination and typographic detail.

Please cite the original version. 


\section{Handbook of Drought and Water Scarcity}

Vol. 1:

Principles of Drought and Water Scarcity

\section{Chapter 32}

\section{Social Aspects of Water Scarcity and Drought}

\section{Johanna Hohenthal and Paola Minoia}

Department of Geosciences and Geography, University of Helsinki, Finland 


\section{Table of Contents}

Page

32.1. Introduction

32.2. Definitions 9

32.2.1 Water Stress/Scarcity and Responses: Supply and Demand $\begin{array}{ll}\text { Management } & 9\end{array}$

$\begin{array}{ll}\text { 32.2.2 Water Poverty } & 11\end{array}$

$\begin{array}{lll}\text { 32.2.3 Drought } & 12\end{array}$

32.3. Theoretical Concepts 14

$\begin{array}{lll}32.3 .1 & \text { Vulnerability } & 14\end{array}$

$\begin{array}{lll}32.3 .2 & \text { Resilience } & 15\end{array}$

$\begin{array}{lll}\text { 32.3.3 Adaptation } & 18\end{array}$

32.4. Case Studies 20

32.4.1 Drought Resilient Socio-Ecological Systems: Tuareg

$\begin{array}{lr}\text { People } & 20\end{array}$

32.4.2 Drought Adaptation in the Midst of the Global Environmental

Change: Experiences from Southern Europe and Africa 21

32.4.3 Power, Governance and Water Scarcity: The West Bank 24

32.5. International Responses to Water Scarcity and Droughts 25

32.6. Summary and Conclusions 27

32.7. References 28 


\section{Author's Biography}

Johanna Hohenthal is a doctoral candidate at the Department of Geosciences and Geography,

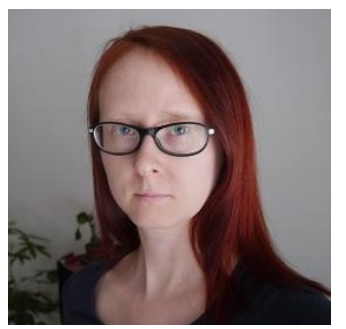
University of Helsinki, Finland. Her PhD research focuses on Development Geography, human-environment interactions, local ecological knowledge, participatory methods, migration and political ecology of water.

Paola Minoia is an adjunct professor and senior lecturer in Development Geography at the University

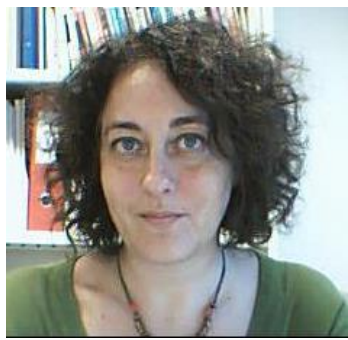
of Helsinki, Finland. Her research mainly focuses on political ecology and community participation in water and irrigation management in Africa. 


\section{Preface}

Water scarcity and droughts are socio-environmental hazards that affect the lives of millions of people every year. This chapter examines the multi-faceted dimensions of these phenomena and their implications to human societies. Various aspects will be considered, including the relation with climate change, economic and socio-political dimensions, under the main focus of development studies. The introductory section discusses water scarcity and drought in the light of the international development goals and global environmental change. The second part will provide some popular definitions of concepts and measures, i.e., water scarcity/stress indicators and management strategies, water poverty and drought. The third part will consider relevant social-environmental concepts that are discussed in literature such as vulnerability, resilience, and adaptation. The fourth part will present case studies especially from Europe, Africa and the Middle East, to illustrate the relevance of human (including socio-cultural-political) structures shaping adaptation to drought. In this line, water scarcity and drought will be studied: 1) as a normal condition in some areas of the world (e.g., in the Saharan and Sahelian belts of Africa), where populations have established resilient socio-ecological systems; 2) in terms of climate change and progressive deterioration of the environment to which communities have either been able to adapt to (e.g., in southern Europe), or have been forced to experience crises, poverty and migrations (e.g., in Sudan, Morocco, Kenya); and 3) in terms of conflicts and residential segregation that makes water inaccessible to certain groups (e.g., in the West Bank). Finally, this chapter will conclude with some international conventions and regulations, like the UNFCCC and the European guidelines for drought risk management, addressing social problems related to drought. 


\subsection{Introduction}

All human populations across latitudes are sometimes affected by varying climate conditions, including periods of droughts. Drought is 'a creeping phenomenon', whose impacts extend over large regions and accumulate as long as the drought proceeds, so that they can still be felt after the meteorological phenomena initiating the drought are gone ([109], p. 5). Prolonged droughts are caused by several interlinked environmental and societal variables. Some societies also suffer from a more permanent water stress or scarcity. The impacts of water scarcity and droughts on societies vary spatially depending not just on their physical characteristics (e.g., drought frequency, duration, magnitude of precipitation deficit) but, above all, on the vulnerability, resilience and adaptive capacity of the affected societies. Drought and water scarcity affect people directly by reducing the amount of safe drinking water and waterborne sanitation possibilities, which lead to increased health and morbidity risks. They also harm food production by reducing the water available for rainfed and irrigated crops. Lack of water causes general malfunctioning of the crucial ecosystem services. The impacts extend also to the other domestic and industrial activities and national economies. The drought mortality risk is the highest in Sub-Saharan Africa, whereas the largest risks for economic losses caused by droughts lie in more developed nations in West and South Europe, North and Central America, Middle East, Australia and north-eastern China ([83], [17]). In case of large catchments, dry conditions have also caused tensions between upstream and downstream water users, both in the Global South and North, either nationally or internationally (e.g., among Sudd wetland's users in Southern Sudan [13], or between Spain and Portugal for the shared Tagus river [52]).

Relation between drought, water scarcity and poverty has been considered by the international community and particularly by the UN agencies. It is now addressed by the Sustainable Development Goal (SDG) 6 "Ensure access to water and sanitation for all" ([4], [89]), following up on the previous Millennium Development Goal (MDG) 7 and its subtarget 10, aiming at halving 'the proportion of people without sustainable access to safe drinking water and basic sanitation by 2015' ([94], p. 103). 
The global target of accessing the improved drinking water sources was met already in 2010, five years before the target date [91]. This happened in spite of significant population growth, indicating that demographic increase is not the sole cause of water scarcity. However, according to the UN MDG Report 2015 [91], there are still many regions, which did not meet the goal (e.g., Oceania and Sub-Saharan Africa) and access to safe drinking water still continues to be unequally distributed in the world. It was estimated that globally 663 million people lacked access to improved water sources in 2015, the proportion being larger in rural than urban areas. In addition, nearly half of all people without improved drinking water lived in Sub-Saharan Africa. Moreover, the improved drinking water sources have not been able to guarantee adequate water quality, meaning that the real number of people without access to safe drinking water may be higher than the official estimates suggest [90].

It is also questionable, what is the sufficient quantity of water that people should have access to. For example, according to Basic Human Water Requirements defined by Gleick (1996) [36], each person needs 50 liters of water for the basic drinking, hygiene, sanitation and food preparation purposes per day. On the other hand, UNDP (2006) [93] suggests that the minimum universal human right to water is 201 per day per person, which is enough for drinking and basic personal hygiene. Bathing and laundry needs raise the threshold to 501 a day.

The sanitation target of the MDG 7 was not met globally by 2015 [91]. According to the UN MDG Report 2015 estimation, 68 per cent of the global population had access to improved sanitation in 2015, while the target was 75 per cent. The progress has been slowest in Sub-Saharan Africa.

Drought, lack of access to water and sanitation, and poor freshwater circulation also inevitably lead to other problems addressed by the development goals. Unsecure water reduces food security (MDG 1, SDG 1 and 2) (e.g., [74], [60], [29]). The capacity of agricultural systems to cope with drought has reduced in semi-arid and dry sub-humid tropical areas along with the agricultural expansion during 
the past 50 years [14]. This is caused by the decreased biodiversity and loss of ecosystem services in the agricultural landscapes and use of few high-yielding, but stress-sensitive crops ([14], [27]). Globalization of the food supply and processing network has led to that drought in some important food production areas of the world increases food prices across the globe [58]. Droughts occurring in world's key food-exporting areas in Australia, Brazil, Canada, Russia and the USA are especially problematic in this sense.

Water scarcity also causes interruptions to education (MDG 2, SDG 4), especially for young women (MDG 3, SDG 5) (e.g., [39], [92], [102]) and it decreases poor families' health and capacity to care for their children (MDG 4 and 5, SDG 3) (e.g., [11]). Lack of water reduces general hygiene increasing spreading of diseases (MDG 6, SDG 3 and 6) (e.g., [69], [70], [114]). While drought may reduce the breeding sites of the mosquitoes hosting malaria parasites ([79], [56]), in cases when there are permanent water sites in the vicinity of the housing that are not rewashed by rain water during droughts, the occurrence of malaria may remain high or even increase [38].

Above all, devastating droughts and permanent water scarcity call for integration of different sectors of the society at different scales, from utilizing local knowledge in water and land resource management and eventually, until enhanced international cooperation within transnational basins (e.g., Nile Basin Initiative, [65]) or globally (e.g., WASH projects, [98]) (MDG 8, SDG 6, 15-17). International cooperation is becoming even more important in the face of the global environmental change, which is currently the main driving force of water stress in arid and semi-arid regions of the world. In the future, especially climate change will accelerate the pressures over the scarce available resources. However, the mismanagement of water and land resources causes additional pressures, which exacerbate the impacts of droughts.

According to the fifth assessment report of the Intergovernmental Panel on Climate Change [49], 
Climate change is projected to reduce renewable surface water and groundwater resources significantly in most dry subtropical regions (high agreement, robust evidence). This will exacerbate competition for water among agriculture, ecosystems, settlements, industry and energy production, affecting regional water, energy and food security.

In addition, the report states that:

Climate change is likely to increase the frequency of meteorological droughts (less rainfall) and agricultural droughts (less soil moisture) in presently dry regions by the end of this century [...] There is no evidence that surface water and groundwater drought frequency has changed over the last few decades, although impacts of drought have increased mostly due to increased water demand.

The hotter and dryer climatic conditions will also increase the forest fire risk all over the world (e.g., [5], [32]). This will cause increased economic losses among people whose livelihoods are dependent on forests and threatens the safety and property of those who live in forested areas.

Another global phenomenon, urban growth, threatens the surface and groundwater supplies in waterscarce regions and increases the risk of urban drought both in developing and developed countries [68]. This is exacerbated by the increasing water demand for domestic, commercial and industrial use brought by the economic growth [58]. The effects of local or seasonal urban water scarcity are typically mitigated through investments in water storage and transportation infrastructure in cities with sufficient financial resources, whereas poorer cities have less means to cope with drought and are thus more vulnerable to water shortage and contamination from industrial, agricultural and human waste.

This chapter highlights the social aspects of water scarcity and drought. After an introduction of the key concepts - water stress and scarcity, water poverty, drought, vulnerability, resilience and adaption - some case studies will be explored. The first case represents drylands in which populations 
have established drought resilient socio-ecological systems (e.g., the Saharan and Sahelian belts of Africa). The second case considers situations of risks caused by climate change and progressive environmental deterioration, where locals have either responded through adaptation measures (e.g., in southern Europe), or have been disempowered by structural impeachments. This latter situation has brought further crises and poverty, or migration that is seen as an ultimate adaptation means (e.g., in Sudan, Morocco and Kenya). Third, the dynamics between drought, governance and power is analysed in terms of conflicts and residential segregation that make water inaccessible to certain groups and impeach migration. This is the case of the so-called entrapped communities (e.g., in the West Bank). Relevant international conventions and regulations to respond to the drought crisis, like the UNFCCC and the European guidelines for drought risk management, conclude the chapter.

\subsection{Definitions}

\subsubsection{Water Stress/Scarcity and Responses: Supply and Demand Management}

According to the Falkenmark Index, $1700 \mathrm{~m}^{3}$ of water per inhabitant is considered the limit of water stress in an average year, while the threshold for water scarcity, below which life and food production systems are endangered, is set as $1000 \mathrm{~m}^{3}$ of water per inhabitant per year [26]. In 2007, more than ten countries in the world were considered suffering from water stress and over twenty countries were facing water scarcity [95]. In most countries, water scarcity is not just based on the physical scarcity of water in local water reservoirs or the large number of water users, but the scarcity of economic and instrumental resources, such as money, capabilities, technologies and infrastructure that determine the state of water supply [77].

A point of criticism to the quantitative approach under water stress and scarcity indicators is that they are usually applied at the national or large regional scales, and overlook issues of equity in water distribution, rights of access, quality standards and ecological sustainability. For example, in 
countries and areas where there are major technical constraints (e.g., scarcity of fresh surface water resources and high costs of desalination of sea water and rain water harvesting in Malta [30]) or political restrictions (e.g., control of Palestinian water consumption by Israel [85]) in water use, the ratio of exploitable water resources to total renewable resources is typically low [31]. Furthermore, population of a country is also almost always reliant on water sources of other countries, which produce the goods that are imported and consumed in that country. This virtual water, which is 'embedded' in the production process [2], should be taken into account in calculating the amount of used water.

Water accessibility is also a key issue, and usually overlooked by national statistics. However, it is difficult to define, because it is based on a complexity of questions, concerning the appropriate distance to the water source or the supplied water (how far?), affordable price (what is a suitable or fair price?) and rights to water (Who is entitled to use it? Are uses restricted or is access to water considered a basic human right for all?). It must also be noted that there are no universal standards regarding the adequate quality of the available water and, in fact, there are many different national and international guidelines (e.g., [108], [22]). Measures of water stress and scarcity do either not take into account how the water is extracted. Currently, especially groundwater abstraction exceeds recharge in many parts of the world [100].

In line with Malthusian considerations of demographic growth as the main factor endangering natural resources, the concepts of water stress and scarcity support ideas in policy making that solution should be found by the strategies of either reducing consumer numbers or increasing water supply. As a matter of fact, policies that have worked through the water/population ratio, have been mostly enforced by authoritarian regimes and/or other powerful actors, operating by the means of large-scale dams, reservoirs, canalizations and intra-basin connections ([61], [103]). In some critical situations, this goal has also been accomplished by internal displacement or voluntary migration, in order to 
decrease the number of residents in overstressed areas, and thus, to release pressure over local water/natural resources. One example is the "New Valley project" that was supposed to mobilise farmers from the Nile Delta to the Western Oases in Egypt [28]. So conceived, the so called supply side management approach includes the mechanisms of space control, governing environmental resource management, land rights and even human consumption.

Recent policy documents (e.g., [103], [24], [7]) advise nations to apply these conventional supplyside tools only as ultimate options, because of their heavy impacts. For example, building a dam may cause losses of land and habitats, resettlement of people, social and political conflicts [103] as well as changes in local and global climate [7]. Alternative options, still on the supply side management, would be to apply groundwater recharge, rainwater harvesting, wastewater recycling, desalination of sea water and fog water collection [59]. However, these options have still been far less utilized than dams and other "hard" infrastructures.

More emphasis is, however, given nowadays to water demand management, including all types of either technical or "soft" tools (e.g., regulations, fiscal tools, education) leading to the effective decrease in consumption [112]. Restoration of networks to decrease leaking, rationalized irrigation and in general, increased efficiency in water allocations in productive processes, may all compose sustainable strategies for decreasing water stress and scarcity.

\subsubsection{Water Poverty}

Other approaches have tried to link water-related issues more closely with socio-environmental factors. One example is the Water Poverty Index (WPI), which provides a more qualitative measure for assessing progress and establishing development priorities and water functions at the community level [82]. Influenced by the Sustainable Livelihood Approach that is anthropocentric and promotes sustainability built on local strengths ([16], [80]), the WPI is a descriptive index formed by weighted 
average of five components: 1) physical availability (including amount and quality) of surface and groundwater resources; 2) accessibility (time and distance) to safe water that can be used for drinking, cooking and industrial use; 3 ) people's capacity to manage water interpreted as income to allow the purchase of improved water, and education and health; 4) various usage of water, for example, for domestic, agricultural and industrial purposes; and 5) environmental integrity related to water resources and ecosystem goods and services from aquatic habitats. Particularly, when applied at the local scale, this index provides information about the diverse elements that may lead to critical situations like desertification and increased poverty, and about specific factors proving vulnerability or, on the contrary, capacity to adapt to stress. In this way, it has potential for informing decisionmakers about more specific areas for intervention that may include environmental protection or other "soft" initiatives enforcing community's capacity to respond and adapt to droughts and other shocks.

\subsubsection{Drought}

Drought is 'a catastrophic non-event' that originates from a deficiency or absence of an expected precipitation ([104], p. 153; [110]) and causes or enhances the existing water stress or scarcity in the affected area. The duration of drought varies from short dry spells lasting for a few weeks to several months or years, even decades. However, unlike water scarcity, drought is a temporal phenomenon and can occur also in generally humid areas of the world, like northern Europe ([9], [42]). Droughts should also be distinguished from aridity and normal dry seasons typical of tropical and sub-tropical areas of the world ([104], [109]).

Drought is conceptualized as a phenomenon for which one universal definition does not exist [109]. The definition depends upon disciplinary perspectives and needs of those who suffer from the impacts. Based on 150 definitions of drought, Wilhite and Glantz (1985) [110] have classified drought into distinctive meteorological, agricultural, hydrological, and socioeconomic and political drought types, which are still commonly used in the drought literature. This classification describes the 
emergence of drought impacts in different phases of the hydrological cycle [18] and the longer the duration of the drought event, the smaller becomes the relevance of precipitation deficiencies and the larger becomes the role of human and social aspects [109]. For example, Falkenmark and Rockström (2008) [27] have shown that rainfall deficit in dryland areas is not as significant factor addressing drought as it is commonly thought. Currently, the typical low productive systems $(<1 \mathrm{t} / \mathrm{ha}$ yield of staple grains), for example, in sub-Saharan Africa use less than 15 per cent of the seasonal rainfall (blue water) for production, while a higher proportion of water is wasted through surface runoff and interception flow ([72], [73]). Instead, agricultural droughts and dry spells are primarily related to soil water deficit and poor plant water availability and uptake (green water), which are caused by poor agricultural management.

Lack of precise definition makes it difficult to determine the onset, duration and severity of drought. Several quantitative drought indices have been developed to analyse different types of droughts, (e.g., Standardized Precipitation Index [57], Palmer Drought Severity Index [67], Soil Moisture Deficit Index and Evapotranspiration Deficit Index [64]), but these are often limited to certain types of areas and certain time periods. They also commonly fail to take into account the social aspects affecting the water demand and supply.

From a social perspective, it is important to notice that also land use may lead to changes in water demand or alter the water storage capacity of the ecosystems leading to more frequent or more severe dry spells and droughts ([110], [55]). For example, it has been unclear whether the drought in Sahel in the 1970s and 1980s was caused by climatic factors, increased population, land use change or a combination of all these factors [45]. In the worst cases, land use changes and increased dry spells may lead into desertification in semi-arid areas of the world [51]. In the humid latitudes of the world, droughts occur less frequently, but there also the increased water demand and competition between different uses may enhance water scarcity during low precipitation periods. Therefore, prolonged dry 
spells are always caused by intertwined natural and social factors [110]. Human societies are also affecting drought occurrence indirectly by increasing the amount of greenhouse gases in the atmosphere, which leads to warming, higher potential evapotranspiration, and changes in global circulation affecting the distribution of precipitation on Earth ([87], [46]). For these reasons, water governance has emerged as a new topic in recent years [40].

\subsection{Theoretical Concepts}

In this part, three concepts - vulnerability, resilience and adaptation - are presented. They are widely used in socio-ecological system research ([19], [63]) and relevant to analysing water scarcity and droughts, and their impacts from a socio-ecological perspective (e.g., [99], [78], [107]). These terms are interrelated and their presence varies within different ecosystems and societies across spatial scales.

\subsubsection{Vulnerability}

Vulnerability has several definitions, but on a basic level it can be described as 'susceptibility to damage or harm' ([19], p. 366) or, more specifically, 'the propensity of exposed elements such as human beings, their livelihoods, and assets to suffer adverse effects when impacted by hazard events' ([12], p. 69). Vulnerability of a society is determined not just by its physical environment and the natural hazard occurrence in that, but above all, the complex economic, political and social characteristics of that society [53]. Vulnerability is a concept through which a natural event, such as precipitation deficiency, is transferred to a socially constructed hazard - a drought [12].

Vulnerability has three components: exposure, sensitivity and adaptive capacity. Mumby et al. (2014, p. 23) [63] define exposure as 'the degree to which a system is exposed to a given stressor', sensitivity as 'the degree to which a stressor impacts the system' and adaptive capacity as 'the potential for the 
system to adjust or cope with the impact'. When exposure and/or sensitivity of a system are high and/or its adaptive capacity is low, the system is vulnerable and it has a decreased capacity to recover from extreme events, such as droughts, and adapt to change over longer term. Vulnerability of a system can be assessed by measuring different attributes of these components (e.g., diversity of livelihood opportunities for adaptive capacity), assigning them scores and combining them into an overall vulnerability index. Vulnerability assessment is the essential part of risk management and requires both social and natural science perspectives [50] and complementing the quantitative metrics with qualitative approaches [12].

Vulnerability is normally assessed concerning a certain hazard, but there are also some features, such as poverty or weak social support networks that increase the general vulnerability of a society to all types of hazards [12]. Vulnerability is also increased by the inadequate communication or wrong perceptions of the risk. IPCC sees the high vulnerability and exposure as mainly 'an outcome of skewed development processes, including those associated with environmental mismanagement, demographic changes, rapid and unplanned urbanization, and the scarcity of livelihood options for the poor' ([12], p. 70). The roots of vulnerability may thus extend long back to the history, changes in politics, governance and power relations.

\subsubsection{Resilience}

Resilience is a more multidimensional concept than vulnerability and has sometimes been blamed for being ambiguous, malleable and thus politically risky [71]. Nevertheless, resilience is a popular term that is widely applied in various fields, including those concerning with social ecological systems, disaster and risk reduction, and climate change [10]. Some scholarly institutions, such as Resilience Alliance and Stockholm Resilience Center, have even wedded their research to this concept.

Traditionally, different definitions of resilience have highlighted the capacity of a system to undergo 
change and withstand disturbances and shocks and still maintain the system in the same state [105]. Resilient agricultural systems, for example, can be characterized as being capable of re-organizing themselves and securing water availability at times of climatic shocks, such as sudden or frequent dry spells [27]. From the resilience perspective, reaching the water balance is not as important as increasing the magnitude of the water deficit that the system can absorb before it is forced to reorganize itself [44]. Sometimes, distinction is made between ecological, engineering and social resilience. For example, according to Falkenmark and Rockström (2008) [27], investments in agricultural development and improved soil management can enhance ecological resilience to drought, whereas social resilience can be increased through social transformation, such as searching for alternative livelihood sources or migration.

Some definitions have seen vulnerability and resilience either as 'opposites or two sides of the same equation on a continuum', whereas some have seen those more clearly as discrete concepts ([53], p. 440). Following the latter perception, vulnerability can be understood as a susceptibility or a 'degree of potential for loss' ([53], p. 441), whereas resilience as a descriptive concept focuses especially on the magnitude of the disturbance that the system is able to withstand and the direction of its recovery trajectories [63]. Nevertheless, high vulnerability is still associated with the low resilience of a system.

Recently, several critical reviews have discussed the different ways to use the concept of resilience. Some important points can be raised from these reviews. First, Turner (2013) [88] shows that even though resilience thinking emerged partly as a response against structuralist equilibrium thinking in ecology [33] and thus, resilience scholars have attempted to disentangle from ecological explanations, they have still continued to embrace systems-modeling perspectives rather than looking at the differences among the entities that constitute a system, at the same time neglecting the internal, endogenous and social dynamics of a system [10]. Instead, a system is seen as being disturbed only 
by external or exogenous forces. Although resilience theorists acknowledge the importance of internal social factors (e.g., [27]), their approach is still too far focused on positivist knowledge production, quantitative increase of social and financial capital and searching of political legitimacy instead of genuine interaction [88]. However, revealing vulnerabilities and enabling the true transformation of power relations within societies, would require less conservative (i.e., less focused on the persistence of a system) and less reductionist (i.e., seeking other than technical solutions to problems) approaches.

A second important point rises from the review by Weichselgartner and Kelman (2014, p. 2) [105] who suggest that "resilience should be transformed from a mainly descriptive concept ('what is done') into one which includes a normative agenda ('what ought to be done')". The ecological resilience approach has not traditionally had similar normative commitments as, for example, political ecology approach [88]. However, as Turner (2013) [88] has pointed out, when resilience is used to describe not just ecological dynamics but also socio-ecological dynamics - like in the case of drought and water scarcity - it is likely to become more normative. According to Weichselgartner and Kelman (2014) [105], this is manifested by definitions of resilience that integrate proactive and transformative aspects into the concept and link it to equity, power, justice and social capital.

According to a review by Brown (2014) [10], the social turn in the resilience concept has occurred within the recent discussion on the global environmental change and mainly through the emergence of three key topics. First, the concept of community resilience has integrated ecological and social ecological systems (SES) perspectives on resilience with human development, psychology and wellbeing research (see e.g., [81] regarding water security). The second topic, transformation, generally means adjustments in all system levels and scales from individuals to institutions and from ecology to economy, which often occur through learning and innovations [10]. It does not fit well into the conservative 'bounce back' perspective of the ecological resilience, but it is essential for the 
'bouncing forward' [54] perspective that has emerged in the recent social resilience scholarship. It aims at avoiding the possibility of maintaining the system in an undesirable state, which is still resilient, but is dominated, for example, by poverty, corruption and exploitation, which have exposed the system to the hazard in the first place and make the transformation of established social processes and structures and recovery from the disaster difficult [105]. The third topic identified by Brown highlights the organizational power of resilience that the communities can use 'to challenge the status quo and to design and shape alternative futures' ([10], p. 113). It has been used for example to extend or move away from the conventional sustainable development concept.

\subsubsection{Adaptation}

Adaptation is the adjustment in natural or human systems in response to actual or expected climatic stimuli or their effects, which moderates harm or exploits beneficial opportunities. For example, temporary labor migration is a common way to adapt to unsecure climate conditions among the subsistence and small-holder families, whose livelihoods are largely dependent on agriculture [58]. Rural-urban and even rural-rural mobilities are, most commonly, temporary or seasonal strategies for complementing household revenues and increase access to new assets, such as seeds from drought tolerant crop varieties, irrigation infrastructures, micro-financing systems and insurances. Instead, long-term migration is considered an ultimate option or adaptation measure.

With regard to climate change, adaptation is an anticipatory and proactive process, which aims at identifying the possible future impacts and vulnerabilities rather than focusing on emergency responses [8]. Adaptation policies should especially take into account the dynamic nature of vulnerability and exposure to risks and include the assessment of their potential spatial and temporal change under different development scenarios [12]. The long term consequences and sustainability of the adaptation strategies should also be considered so that the short term risk reduction does not lead to increased vulnerability and exposure in the longer term. 
Adaptation options designed to ensure water supply during average and drought conditions require integrated demand-side as well as supply-side strategies [7]. Adaptation can be enhanced, for example, by improving the water use efficiency in agriculture through specific irrigation techniques, reducing wind erosion and increasing soil water storage with crop residue (conservation agriculture), increasing the cost effectiveness of plant breeding by allowing local farmers to participate into it and changing cropping patterns through earlier sowing and using shorter duration and less sensitive crops [86]. On an institutional level, Integrated Water Resources Management (IWRM) provides an important framework to achieve adaptation measures across socio-economic, environmental and administrative systems. On a technical level, institutions could use, for example, crop insurances, introduce payment for ecosystem services, explore and diversify the livelihood options in the area, provide capacity building, train people in drought preparedness, organize early warning systems and enhance community participation into policy making in order to assist the adaptation of the rural poor to increasing water scarcity and droughts.

The adaptation measures may contribute to mitigating the detrimental impacts of climate change for example through carbon sequestration [86]. Mitigation measures, aiming at reducing the greenhouse gas emissions in general, can reduce the magnitude of the impacts of global warming on water resources, in turn reducing the adaptation needs [7]. However, they can have considerable negative side effects, such as increased water requirements for afforestation/reforestation activities or bioenergy crops, if projects are not sustainably located, designed and managed. On the other hand, water management policy measures, e.g., hydrodams, can influence greenhouse gas emissions. Hydrodams are a source of renewable energy but they produce greenhouse gas emissions themselves. 


\subsection{Case Studies}

This section provides brief case studies that illustrate the concepts and multiple dimensions of water scarcity and droughts discussed in previous sections. First, an example of a drought resilient socioecological system is given. This is followed by examples of countries where climate change is already increasing drought occurrence and discussion about the ways these countries have either managed or failed to adapt to the changes. Third case describes the emergence of water scarcity under unequal power relations.

\subsubsection{Drought Resilient Socio-ecological Systems: Case of the Tuareg People}

According to the Millennium Ecosystem Assessment [60], 35.5 per cent of the world population lives in dryland areas. Rural populations in these areas are used to recurring droughts and have thus developed adaptation measures that are suitable for the characteristics of drought in their region [58]. For example, pastoralism, nomadism and semi-nomadism have evolved as an adaptation to variable environmental conditions and frequently occurring droughts.

Socio-ecological crises arise when traditional livelihoods are challenged by external pressures, either environmental or socio-political. For example, in Sahara-Sahel, the Tuaregs have traditionally practiced pastoralism and nomadism to face aridity and seasonal changes. However, the formations of postcolonial states of Algeria, Mali, Niger, Burkina Faso and Libya with consolidated borders have constrained their free movements and increased their vulnerability. Rainfed drought tolerant crops of millet and sorghum were also integrated into the livelihoods of the Tuaregs as a means to adapt flexibly to short seasonal rains and floods [34]. States' efforts to enforce borders and prevent uncontrolled people's mobility have been achieved through other policies, like sedentarization programmes of nomadic ethnic groups of the north, and delegation of power to ethnical groups from the southern provinces. Urban expansion is concentrated in the South where new settlers shelter in marginal slums with poor services. It is thus clear that policies have decreased the poorest groups' 
access to water resources. Tensions have grown and led to civil and international wars across state borders.

\subsubsection{Drought Adaptation in the Midst of the Global Environmental Change: Experiences from Southern Europe and Africa}

Long-term changes in global climate, permanent physical or chemical soil degradation and permanent vegetation damage produce irreversible changes in ecosystems. In the worst cases, this leads to the increase of disastrous droughts and even desertification. These ongoing and proposed future changes call for the immediate enhancement of social resilience of the societies and drought management and adaptation planning.

Southern Europe and Mediterranean area are well-known examples of regions suffering from water scarcity and recurring droughts. Several countries, especially on the southern side of the Mediterranean, suffer from water scarcity [48]. For example, in Egypt and Libya, water demand clearly exceeds the available resources. Large part of the total water withdrawal is consumed for irrigated agriculture. Water consumption is also growing due to increasing economic and social needs, such as upgraded standards of living, as well as growing tourism.

Droughts have become more frequent in the Mediterranean area especially since the 1970s causing large economic losses [48]. They are expected to become even more frequent and long-lasting in the future due to climate change [49]. In addition, population growth in many countries decreases the renewable water resources per capita. Along with water quantities, also water qualities are decreasing. This is caused especially by the increased use of agrochemicals. Overuse of aquifers during droughts also contributes to the degradation of groundwater quality.

In Southern Europe, many adaptive measures have been taken to cope with water scarcity and 
droughts. For example, in Spain, hydraulic infrastructure has been built to transfer water to the drier parts of the country since the ancient times [20]. Since most of the water courses are already regulated by large dams, desalination of sea water and wastewater reuse are now providing alternative means to expand the available resources in the most vulnerable areas. Spain also has large underground water resources, which help to alleviate the water shortages especially in the driest areas. However, the over-exploitation of some aquifers has led to the intrusions of saline water in some coastal areas. During a recent drought in 2004-2008, water demand management was also effectively applied by River Basin Authorities who provided economic compensations to farmers renouncing irrigating their fields. The farmers were also able to exchange their water use rights with each other. The relatively effective adaptation has been made possible by the Spanish national legislation that obligated each River Basin Authority to elaborate a drought management plan (DMP) and send drought indicator data to the national monitoring database periodically. The DMPs were approved in 2007 and they have proved to be effective in managing water resources during droughts.

In the less developed countries of the southern side of the Mediterranean, increased droughts and worsening water scarcity have led to poverty crises and forced people to rely on ultimate means of adaptation, such as migration. For example, in Morocco, recurring droughts combined with fluctuations in agricultural yields, weak income and loss of social safety nets have increased poverty and adoption of national or international migration as a key strategy for sustaining livelihoods since the 1980s ([84], [76]). Remittances from the migrants provide additional income for the families living in drought prone areas. However, the climatic conditions are not the sole driver of migration, but the spatial differences in prosperity within the country are also enhancing the internal migration from the economically and infrastructurally marginalized southern parts to the wealthier north. This dichotomy has its roots in the colonial period when the French divided Morocco into Northern 'useful' and Southern 'necessary' or 'useless' parts. 
In further south, the history of Sudan has also seen many droughts, some of them combined with severe famines and conflicts leading to involuntary displacements of people [41]. It is also likely that the number of devastating droughts will increase due to climate change in this area in the future, creating a need to enhance the resilience of the country [66]. This is done through adaptation methods including water harvesting, new irrigation methods, expansion of food storage possibilities, managing rangelands and grazing in order to reduce erosion, planting backyard farms to increase food supply and income, supplying microcredit and forming and educating community groups.

According to Billé et al. (2013) [8], nations which have more pressing and concrete problems to concern with, are difficult to be encouraged to allocate resources to adaptation to climate change. Therefore, they suggest that the adaptation strategies should start 'addressing immediate and short term needs in line with national development priorities while laying the groundwork to adapt to future changes' (p. 238). Another problem is that there has been a tendency to allocate most resources to small-scale, pro-poor adaptation projects, which leads to fragmentation of adaptation and detaching the local vulnerability from the larger scale drivers, such as national political and economic choices. For example, in Morocco, the small-scale projects have not adequately recognized the national policies, which support inter-basin water transfers to Marrakech and coastal areas for tourism at the expense of the agricultural water supply. Small-scale adaptation projects are important, but they should not be the main channel of implementing the country's adaptation strategy. Increasing of regional cooperation between different projects is of utmost importance.

In Taita Hills in south-eastern Kenya, the fragmentation of land ownership that originated from the national land reform in the 1960s, has caused environmental deterioration and decreased water availability [43] leading to continuous labour migration to the big cites of Mombasa and Nairobi. However, the migration has become such a common practice that the local people do not really recognize the underlying drivers of this mobility, but consider it just a normal part of life. The 
negative consequences of the migration include the loosing of the family ties and increasing workload of the women who are often left behind to take care of the children. In Eastern Africa, precipitation is expected to increase in the future, but cutting down of the forests, increasing erosion and decreasing soil fertility still continue to threaten the livelihoods of the small-scale farmers. Therefore, strengthening of the integrated land and water resources management and cooperation between different stakeholders are urgently needed.

\subsubsection{Power, Governance and Water Scarcity: Case of the West Bank}

In some cases, water scarcity results from conflicts and residential segregation that deteriorates certain groups' access to water. In the Occupied Palestinian Territories (OPT) of the West Bank and Gaza, the government of Israel has set limitations to the Palestinian authorities that restrict them from developing the water and sanitation sector of these areas [25]. Inadequate water supply has led to obstruction of economic development and made Palestinian communities dependent on humanitarian aid. In the OPT, water has become a weapon in a conflict between the Palestinians and the Israeli over the territories that lie between the River Jordan and the Mediterranean. The origin of the conflict dates back to the establishment of the state of Israel in 1948 when over 800000 Palestinians became refugees in the Gaza strip, West Bank and the neighbouring countries (e.g., [113], [35]). In 1967, Israel took over the control of these territories from Egypt and Jordan. At the same time, the control of all the water resources was transferred to the Israeli army. Despite the establishment of the Palestinian Authority in 1994 and negotiations of permanent status agreement, Israel is continuing occupation of the Palestinian areas with illegal settlements and "by-pass" roads.

The water resources of the West Bank are restricted to the underground Mountain Aquifer, which is shared with Israel. The total capacity of the aquifer varies from 679 to 734 million $\mathrm{m}^{3}$ per year depending on whether it is the estimation of the Hydrological Service of the Israel (the latter) or if it is used by the Israeli authorities to decide the quantity of water to be allocated to the Palestinians (the 
former) [3]. The West Bank also shares the Jordan River with Israel, but since the occupation of the

West Bank, Israel has denied access of the Palestinians to the river [1]. Thus the 2.5 million Palestinians of the West Bank have their only source of water from the Mountain aquifer, whereas the water for the 7 million Israeli is abstracted from the Mountain aquifer (400 million $\mathrm{m}^{3}$ per year), from the diverted Jordan River (650 million $\mathrm{m}^{3}$ per year) as well as from the Lake Kinneret of Galilee and the Coastal Aquifer, the latter one being the only source for the 1.5 million Palestinians in the Gaza strip (about ground water salinization in the Gaza Strip see e.g., [106]). Due to the restrictions by Israel, the Palestinians of the West Bank receive only 20 per cent or less of the water of the Mountain Aquifer. The overall extraction of the aquifer exceeds its yearly sustainable yield potentially damaging the quality of the water source due to the intrusion of saline water from the surrounding sources.

The inadequate water supply for the Palestinians is compensated by digging unlicensed wells, making illegal connections to the water lines of the Israeli settlers and buying water from Israel that has extracted it from the Mountain Aquifer. During the driest and hottest periods, the amount of water sold is rationed by the Israeli authorities. One third of the overall water supply to the Palestinians is lost by leakages in the old pipe networks. Fixing or replacing the old infrastructure is practically impossible because the Palestinians should obtain permits for such development projects from the Israeli army [1]. At the same time the water levels in Palestinian wells and springs are decreasing due to the development of the water infrastructure on the Israeli side. Therefore, the water access to Palestinians varies between only 10-70 l per person per day [3].

\subsection{International Responses to Water Scarcity and Droughts}

The severe consequences of water scarcity and droughts and their projected future increase have led to the emergence of national drought management plans in many countries (e.g., [6], [37]). As the 
drivers and impacts of these phenomena cross national borders, international conventions and guidelines are also needed for drought risk management. For example, the Integrated Drought Management Programme (IDMP), launched in 2013 by the World Meteorological Organization (WMO) and Global Water Partnership (GWP), has recently published its own National Drought Management Policy Guidelines highlighting the importance of drought preparedness [111].

United Nations Framework Convention on Climate Change (UNFCCC) has also established a national adaptation plan (NAP) process that provides developing countries information on mediumand long-term adaptation needs for formulating national adaptation plans as well as technical assistance to implement the strategies and programs [97]. The NAPs contain a list of climate change adaptation activities that the national governments will prioritize and thus they have an important role in determining the adaptation pathways and available funding sources [62]. Integration of national water and drought policies into the development of the NAPs is crucial. The UNFCCC guidelines suggest safeguarding food and water security and sanitation using various methods, such as diversifying crop production, promoting water-saving irrigation techniques, soil conservation, land use planning, improved rainwater harvesting, and resilient designs of water infrastructure [96]. They also promote the coordination of adaptation planning between different sectors.

In the European Union, the Water Framework Directive (WFD) 2000/60/EC [23] is the main policy tool addressing the water issues. The WFD aims at improving and protecting the water resources of Europe. However, it has been blamed for being inadequate in addressing the drought situations and providing national level guidelines ([48], [75]). As a response to this, an expert working group led by Italy, Spain and France was established in 2007 within the Common Implementation Strategy of the WFD to assess technical needs. This resulted in the Communication of the European Commission to the Council and European Parliament 'Addressing the challenge of water scarcity and droughts in the European Union' [21]. It highlights integrated approach and demand side management by underlining 
the importance of water saving and improving water efficiency. The working group has also given guidelines for drought management planning at different levels [101]. The recommendations of the expert group have led to the development of European Drought Observatory as well as integration of drought preparedness planning as part of the normal water resources planning in many countries [20]. In addition to this, EU has funded many research programs studying the water scarcity and droughts in Europe that provide valuable information and guidelines to policy making and water management (e.g., ARIDE [15] and MEDROPLAN [47]).

\subsection{Summary and Conclusions}

In this chapter, the multidimensional aspects of water scarcity and droughts have been reviewed with several examples from Europe and Africa showing how the intertwined environmental, historical and societal factors drive these phenomena. The impacts of the water disasters on societies vary spatially depending, above all, on the socially constructed vulnerability, resilience and adaptive capacity of the affected societies. Due to their multidimensionality, many key concepts still lack clear and universal definitions accepted by all disciplines. However, this should not act as a barrier to increasing cooperation and action between the academics, policy makers, international organizations and the public.

Relation between water scarcity and poverty has been considered increasingly by the international community and particularly by the UN agencies, and broadly addressed, for example, by the Millennium Development Goals and new Sustainable development goals that set targets to 2030 . International cooperation is becoming even more important in the face of the human-induced global environmental change, which is currently the main driving force of the water stress globally. Climate change together with additional pressures from the mismanagement of water and land resources is accelerating the pressures over the scarce available resources. Therefore, cooperation between the 
professionals and local communities and integration of local knowledge of drought preparedness, adaptation and mitigation into resilience building and water management are becoming increasingly important.

\subsection{References}

[1] Abu Zahra, B.A.A., 2001. Water crises in Palestine. Desalination 136, 93-99.

[2] Allan, J.A., 1998. Virtual water: a strategic resource global solutions to regional deficits. Groundwater 36(4), 545-546.

[3] Amnesty International, 2009. Troubled waters - Palestinians denied fair access to water. Israeloccupied Palestinian Territories. London: Amnesty International Publications.

[4] Andersson, M. and Minoia P., 2016. Ecological sanitation: a sustainable goal with local choices. A case study from Taita Hills, Kenya. African Geographical Review (online) 1-17

[5] Aragão, L.E.O.C., Malhi, Y., Roman-Cuesta, R.M., Saatchi, S., Anderson, L.O. and Shimabukuro Y.E., 2007. Spatial patterns and fire response of recent Amazonian droughts. Geophysical Research Letters 34(7), L07701.

[6] Australian Government, 1992. National Drought policy. Available at: http://www.daff.gov.au/_data/assets/pdf_file/0006/924306/national-drought.pdf [Retrieved 30 June, 2014].

[7] Bates, B.C., Kundzewicz, Z.W., Wu, S. and Palutikof, J.P. (eds.), 2008. Climate Change and Water. Technical Paper of the Intergovernmental Panel on Climate Change. Geneva: IPCC Secretariat.

[8] Billé, R., Downing, T., Garnaud, B., Magnan, A., Smith, B. and Taylor, R., 2013. Adaptation strategies for the Mediterranean. In: A. Navarra and L. Tubiana (eds.), Regional Assessment of Climate Change in the Mediterranean: Volume 2: Agriculture, Forests and Ecosystem Services 
and People. Advances in Global Change Research 51, pp. 235-262. Springer Science+Business Media Dordrecht 2013.

[9] Bradford, R.B., 2000. Drought events in Europe. In: Vogt J.V., Somma F. (eds.) Drought and drought mitigation in Europe. Advances in Natural and Technological Hazards Research 14: 7-20.

[10] Brown, K. 2014. Global environmental change I: a social turn for resilience. Progress in Human Geography 38(1), 107-117.

[11] Buor, D., 2004. Water needs and women's health in the Kumasi metropolitan area, Ghana. Health and Place 10, 85-103.

[12] Cardona, O.D., van Aalst, M.K., Birkmann, J., Fordham, M., McGregor, G., Perez, R., Pulwarty, R.S., Schipper, E.L.F., Sinh, B.T., 2012. Determinants of risk: exposure and vulnerability. In: Field, C.B., Barros, V., Stocker, T.F., Qin, D., Dokken, D.J., Ebi, K.L., Mastrandrea, M.D., Mach, K.J., Plattner, G.K., Allen, S.K., Tignor, M., Midgley, P.M. (eds.) Managing the risks of extreme events and disasters to advance climate change adaptation. A special report of working groups I and II of the intergovernmental panel on climate change (IPCC). Cambridge: Cambridge University Press, pp. 65-108.

[13] Cascão, A.E., 2013. Resource-based conflict in South Sudan and Gambella (Ethiopia): When water, land and oil mix with politics. In: Dias, A.M. (ed.) State and Societal Challenges in the Horn of Africa: Conflict and processes of state formation, reconfiguration and disintegration. Lisbon: Center of African Studies (CEA)/ISCTE-IUL, University Institute of Lisbon.

[14] Comprehensive Assessment of Water Management in Agriculture, 2007. Water for food. Water for life. A Comprehensive Assessment of Water Management in Agriculture. London: Earthscan, and Clombo: International Water Management Institute.

[15] Demuth, S. and Stahl, K. (eds.), 2001. ARIDE-Final Report.

[16] Department for International Development, 2000. Disability, poverty and development. London: DFID. 
[17] Dilley, M., Chen, R.S., Deichmann, U., Lerner-Lam, A.I. and Arnorld, M., 2005. Natural Disaster Hotspots: A Global Risk Analysis. Washington D.C: World Bank.

[18] Dracup, J.A., Lee, K.S. and Paulson, E.G. Jr., 1980. On the definition of droughts. Water Resources Research 16, 297-302.

[19] Eakin, H. and Luers, A.L., 2006. Assessing the vulnerability of social-environmental systems. Annual Review of Environmental Resources 31, 365-394.

[20] Estrela, T. and Vargas, E., 2012. Drought management plans in the European Union. The case of Spain. Water Resources Management 26,1537-1553.

[21] European Commission, 2007. Addressing the challenge of water scarcity and droughts in the European Union. Communication from the Commission to the European Parliament and the Council, COM (2007) 414 final.

[22] European Council, 1998. Council Directive 98/83/EC of 3 November 1998 on the quality of water intended for human consumption. Available at: http://eur-lex.europa.eu/legalcontent/EN/TXT/?uri=CELEX:31998L0083 [Retrieved 4 June, 2014].

[23] European Parliament and the Council, 2000. Directive 2000/60/EC, establishing a framework for Community action in the field of water policy. 23 October 2000. Amended version available at: $\quad$ http://eur-lex.europa.eu/legal-content/EN/TXT/?uri=CELEX:02000L0060-20090625. [Retrieved 30 June, 2014].

[24] European Union, 2007. Communication from the Commission to the European Parliament and the Council - Addressing the challenge of water scarcity and droughts in the European Union $\{\operatorname{SEC}(2007) \quad 993\} \quad\{\operatorname{SEC}(2007) \quad 996\} \quad$ Available at: http://eur-lex.europa.eu/legalcontent/EN/TXT/?uri=CELEX:52007DC0414 [Retrieved 4 June, 2014].

[25] EWASH [Emergency Water Sanitation and Hygiene Group], 2012. "Down the drain". Israeli restrictions on the WASH sector in the Occupied Palestinian Territory and their impact on vulnerable communities (March 2012). 
[26] Falkenmark. M., 1989. The massive water scarcity threatening Africa - Why isn't it being addressed. Ambio 18(2), 112-118.

[27] Falkenmark, M., and Rockström, J., 2008. Building resilience to drought in desertificationprone savannas in Sub-Saharan Africa: The water perspective. Natural Resources Forum 32(2), 93-102.

[28] Faggi, P., 1983. Stato e progetti di sviluppo nel Terzo Mondo: il caso di Al-Sheykh Wali (New Valley, Repubblica Araba d'Egitto). Materiali dell'Instituto di Geografia, Padova: Università di Padova.

[29] FAO [Food and Agriculture Organization of the United Nations], 2011. Drought-related food insecurity: A focus on the Horn of Africa. Drought Emergency - Emergency Ministerial-level Meeting. Rome, 25 July, 2011.

[30] FAO [Food and Agriculture Organization of the United Nations], 2003. Review of Water Resources by Country. Water Reports 23. Rome: FAO.

[31] FAO [Food and Agriculture Organization of the United Nations], 2006. Malta water resources review. Rome: FAO.

[32] Flannigan, M.D., Krawchuck, M.a., de Groot, W.J., Wotton, B.M. and Gowman, L.M., 2009. Implications of changing climate for global wildland fire. International Journal of Wildland Fire 18, 483-507.

[33] Folke, C., 2006. Resilience: The emergence of a perspective for social-ecological systems analyses. Global Environmental Change 16, 253-267.

[34] Galles, J., 1984. Hommes du Sahel. Espaces-temps et pouvoirs. Delta interieur du Niger 19601980. Paris: Flammarion.

[35] Gilbert, M. 2012. The Routledge Atlas of the Arab-Israeli conflict. 10 ${ }^{\text {th }}$ edition. New York: Routledge.

[36] Gleick, P.H., 1996. Basic Water Requirements for Human Activities: Meeting Basic Needs. Water International 21, 83-92. 
[37] Government of India, Department of Agriculture and Cooperation Ministry of Agriculture, 2009. Manual for Drought Management. New Delhi.

[38] Govoetchan, R., Gnanguenon, V., Azondékon, R., Fiacre Agossa, R., Sovi, A., Oké-Agbo, F., Ossé, R., Akogbéto, M., 2014. Evidence for perennial malaria in rural and urban areas under the Sudanian climate of Kandi, Northeastern Benin. Parasites and Vectors 7(1), 1-19.

[39] Greed, C., 2004. Inclusive Urban Design: Public Toilets. Oxford: Architectural Press.

[40] Green, C. and Eslamian, S., 2014. Water Governance. In Eslamian, S. (ed.) Handbook of Engineering Hydrology, Ch. 24, Vol. 3: Environmental Hydrology and Water Management, pp. 461-483. Francis and Taylor, CRC Group, USA.

[41] Hamid, G.M., 1996. Population displacement in the Sudan: patterns, responses, coping strategies. Center for Migration Studies Special Issues 13(3). Wiley.

[42] Hannaford, J., Lloyd-Hughes, B., Keef, C., Parry, S. and Prudhomme, C., 2011. Examining the large-scale spatial coherence of European drought using regional indicators of precipitation and streamflow deficit. Hydrological Processes 25, 1146-1162.

[43] Hohenthal, J., Owidi, E., Minoia, P., Pellikka, P., 2015. Local assessment of changes in waterrelated ecosystem services and their management: DPASER conceptual model and its application in Taita Hills, Kenya. International Journal of Biodiversity Science, Ecosystem Services and Management 11, 225-238.

[44] Holling, C.S. and Meffe, G.K., 1996. On command-and-control and the pathology of natural resources management. Conservation Biology 10, 328-337.

[45] Hulme, M., 2001. Climatic perspectives on Sahelian desiccation 1973-1998. Global Environmental Change 11, 19-29.

[46] Huntington, T.G., 2006. Evidence for intensification of the global water cycle: review and synthesis. Journal of Hydrology 319, 83-95.

[47] Iglesias, A., Cancelliere, A., Gabiña, D., López-Francos, A., Moneo, M. and Rossi G. (eds.), 2006. Drought Management Guidelines. European Commission - EuropeAid Co-operation 
Office, Euro-Mediterranean Regional Programme for Local Water Management (MEDA Water) and Mediterranean Drought Preparedness and Mitigation Planning (MEDROPLAN). Available at:

https://sustainabledevelopment.un.org/content/documents/3907MEDROPLAN\%20guidelines _english.pdf [Retrieved 1 February, 2016]

[48] Iglesias, A., Garrote, L., Flores, F. and Moneo, M., 2007. Challenges to manage the risk of water scarcity and climate change in the Mediterranean. Water Resources Management 21, 775788.

[49] IPCC [Intergovernmental Panel on Climate Change], 2014. Impacts, Adaptation and Vulnerability. Contribution of Working Group II to the Fifth Assessment Report of the Intergovernmental Panel on Climate Change. Available at: http://www.ipcc.ch/report/ar5/wg2/ [Retrieved 3 June, 2014]

[50] Kienberger, S., Blaschke, T. and Zehra Zaidi, R., 2013. A framework for spatio-temporal scales and concepts from different disciplines: the 'vulnerability cube'. Natural Hazards 68, 13431369.

[51] Kundzewicz, Z., 1997. Water resources for sustainable development. Hydrological Sciences Journal 41, 467-480.

[52] Llamas, M.R., 1997. Transboundary water resources in the Iberian Peninsula. In: Gleditsch, N.P. (ed.) Conflict and the Environment. NATO ASI Series 33, 335-353.

[53] Manyena, S.B., 2006. The concept of resilience revisited. Disasters 30(4), 433-450.

[54] Manyena, S.B., O’Brien, G., O’Keefe, P. et al., 2011. Disaster resilience: A bounce back or bounce forward ability? Local Environment 16(5), 417-424.

[55] Maracchi, G., 2000. Agricultural drought - a practical approach to definition, assessment and mitigation strategies. In Vogt, J.V. and Somma, F. (ed.) Drought and drought mitigation in Europe. Advances in Natural and Technological Hazards Research 14, 63-75. 
[56] Martin, P.H. and Lefebvre, M.G., 1995. Malaria and climate sensitivity of malaria potential transmission to climate. Ambio 24, 200-207.

[57] McKee, T.B., Doesken, N.J. and Kleist, J., 1993. The relationship of drought frequency and duration to time scales. In Preprints, 8th Conference on Applied Climatology, pp. 179-184. American Meteorological Society, Anaheim, CA, Boston, MA, 17-22 January.

[58] McLeman, R.A., 2013. Climate and Human Migration. Past Experiences, Future Challenges. Cambridge University Press.

[59] Memon, F.A. and Ward, S., 2014. Alternative Water Supply Systems. IWA Publishing.

[60] Millennium Ecosystem Assessment, 2005. Millennium Ecosystem Assessment. Ecosystems and human wellbeing. A framework for assessment. Washington D.C.: Island Press.

[61] Minoia, P., 2012. Mega-irrigation and neoliberalism in postcolonial states: evolution and crisis in the Gharb Plain, Morocco. Geografiska Annaler: Series B, Human Geography 94(3), 269286.

[62] Muller, J.C.-Y., 2014. Adapting to Climate Change and Addressing Drought- learning from the Red Cross Red Crescent experiences in the Horn of Africa. Weather and Climate Extremes $3,31-36$.

[63] Mumby, P.J., Chollett, I., Bozec, Y.-M. and Wolff, N.H., 2014. Ecological resilience, robustness and vulnerability: how do these concepts benefit ecosystem management. Current opinion in Environmental Sustainability 7, 22-27.

[64] Narasimhan, B. and Srinivasan, R., 2005. Development and evaluation of Soil Moisture Deficit Index (SMDI) and Evapotranspiration Deficit Index (ETDI) for agricultural drought monitoring. Agricultural and Forest Meteorology 133, 69-88.

[65] Nile Basin Initiative, 2011. Nile Basin Initiative Member States Benefits Profiles. Available at: http://nileis.nilebasin.org/content/nile-basin-initiative-member-states-benefits-profiles. [Retrieved 23 June, 2014]. 
[66] Osman-Elasha, B., 2009. Building resilience to drought and climate change in Sudan. In The Worldwatch Institute, State of the World 2009. Into a Warming World. Washington, DC: Worldwatch Institute.

[67] Palmer, W.C., 1965. Meteorological drought. Research Paper 45.58 p. Washington, D.C.: US Weather Bureau.

[68] Postel, S., 2000. Entering an era of water scarcity: the challenges ahead. Ecological Applications 10(4), 941-948.

[69] Prüss, A., Kay, D., Fewtrell, L. and Bartram, J., 2002. Estimating the burden of disease from water, sanitation, and hygiene at a global level. Environmental Health Perspectives 110(5), 537-542.

[70] Prüss-Üstün, A., Bos, R., Gore, F., Bartram, J., 2008. Safer water, better health: costs, benefits and sustainability of interventions to protect and promote health. Geneva: World Health Organization.

[71] Reid, R. and Botterill, L.C., 2009. The multiple meanings of 'resilience': an overview of the literature. Australian Journal of Public Administration 72(1), 31-40.

[72] Rockström, J., 2003. Water for food and nature in drought-prone tropics: vapour shift in rainfed agriculture. Royal Society Transactions B Biological Sciences 358, 1997-2009.

[73] Rockström, J., Lannerstad, M. and Falkenmark, M., 2007. Assessing the water challenge of a new green revolution in developing countries. Proceedings of the National Academy of Sciences 104, 6253-6260.

[74] Rosegrant, M.W. and Cline, S.A., 2003. Global food security: challenges and policies. Science 302, 1917-1919.

[75] Rossi, G. and Castiglione, L., 2011. Towards guidelines for drought preparedness and mitigation planning within EU water policy. European Water 36, 37-51.

[76] Rössler, M., Kirscht, H., Rademacher, C., Platt, S., Kemmerling, B. and Linstädter, A., 2011. Migration and resource management in Drâa Valley, Southern Morocco. In: Speth, P., 
Christoph, M. and Diekkrüger, B. (eds.), Impacts of Global Change on the Hydrological Cycle in West and Northwest Africa. Pp. 584-597. Springer.

[77] Seckler, D., Barker, R. and Amarasinghe, U., 1999. Water scarcity in the twenty-first century. Water Resources Development 15(1/2), 29-42.

[78] Sendzimir, J., Reij, C.J. and Magnuszewski, P., 2011. Rebuilding resilience in the Sahel: regreening in the Maradi and Zinder regions of Niger. Ecology and Society 16(3), 1.

[79] Sloof, R., 1961. Field observations on the biting activity of Anopheles koliensis Owen. Trop Geogr Med, 67-76.

[80] Solesbury, W., 2003. Sustainable Livelihoods: A Case Study of the Evolution of DFID Policy. Working Paper 217. London: Overseas Development Institute.

[81] Stebbing, M.S., Carey, M., Sinclair, M. and Sim, M., 2013. Understanding the vulnerability, resilience and adaptive capacity of households in rural Victorian towns in the context of longterm water insecurity. Australian Journal of Water Resources 17(2), 193-201.

[82] Sullivan, C.A., Meigh, J.R. and Giacomello, A.M., 2003. The Water Poverty Index: development and application at the community scale. Natural Resources Forum 27(3), 189199.

[83] Sylvain, P., Sapir, D.G., Below, R., 2012. Annual Disaster Statistical Review 2011. Brussels, Belgium: Center for Research on the Epidemiology of Disasters (CRED).

[84] The World Bank, 2007. Kingdom of Morocco. Moving out of poverty in Morocco. Social and Economic Development Group, Middle East and North Africa Region. Draft Report No. 39992MOR. The World Bank.

[85] The World Bank, 2009. West Bank and Gaza. Assessment of restrictions on Palestinian Water Sector Development. Report No. 47657-GZ. Washington: The International Bank for Reconstruction and Development/The World Bank. 
[86] Thomas, R.J., 2008. Opportunities to reduce the vulnerability of dryland farmers in Central and West Asia and North Africa to climate change. Agriculture, Ecosystems and Environment 126, $36-45$.

[87] Trenberth, K.E., 1998. Atmospheric moisture residence times and cycling: implications for rainfall rates and climate change. Climatic Change 39, 667-694.

[88] Turner, M.D. 2013. Political ecology I: an alliance with resilience. Progress in Human Geography 38, 616-623.

[89] UN [United Nations], 2015. Draft outcome document of the United Nations summit for the adoption of the post-2015 development agenda. United Nations General Assembly 12 August 2015. A/69/L.85. Available at:

http://www.un.org/ga/search/view_doc.asp?symbol=A/69/L.85\&Lang=E [Retrieved 2 February, 2016]

[90] UN [United Nations], 2013. The Millennium Development Goals Report 2013. NewYork: United Nations.

[91] UN [United Nations], 2015. The Millennium Development Goals Report 2015. Available at: http://www.un.org/millenniumgoals/2015_MDG_Report/pdf/MDG\%202015\%20rev\%20\%28 July\%201\%29.pdf [Retrieved 2 February 2016]

[92] UN DESA [United Nations Department of Economic and Social Affairs], 2005. A gender perspective on water resources and sanitation. Background Paper No. 2. DESA/DSD/2005/2. Commission of Sustainable Development, Twelfth Session, 14-30 April 2004, New York.

[93] UNDP [United Nations Development Programme], 2006. Human Development Report 2006. Beyond scarcity: Power, poverty and the global water crisis. New York: UNDP.

[94] UNDP [United Nations Development Programme], 2003. Millennium Development Goals: A compact among nations to end human poverty. New York: Oxford University Press. 
[95] UNEP/GRID-Arendal. 2008. Vital Water Graphics. An Overview of the State of the World's Fresh and Marine Waters (2nd edn). Nairobi, UNEP. Available at: http://www.unep.org/dewa/vitalwater/article48.html [Retrieved 4 June, 2014].

[96] UNFCCC [United Nations Framework Convention on Climate Change], Least Developed Countries Expert Group, 2012. National adaptation plans. Technical guidelines for the national adaptation plan process.

[97] UNFCCC [United Nations Framework Convention on Climate Change], Least Developed Countries Expert Group, 2012. The National Adaptation Plan Process. A brief overview.

[98] UNICEF [United Nations Children's Fund], 2006. Water, sanitation and hygiene strategies for 2006-2015. E/ICEF/2006/6. Available at: http://www.unicef.org/about/execboard/files/066_WASH_final_ODS.pdf. [Retrieved 23 June, 2014].

[99] Vásquez-León, M., 2009. Hispanic farmers and farmworkers: social networks, institutional exclusion, and climate vulnerability in Southeastern Arizona. American Anthropologist 111(3), 289-301.

[100] Wada, Y., 2012. Non-sustainable groundwater sustaining irrigation. GWF Discussion Paper 1205. Canberra: Global Water Forum.

[101] Water Scarcity and Droughts Expert Network, 2007. Drought management plan report. Including agricultural, drought indicators and climate change aspects. Technical report-2008 - 023. Luxembourg: Office for Official Publications of the European Communities.

[102] Water Supply and Sanitation Collaborative Council, 2006. For her it's the big issue: putting women at the centre of water supply, sanitation and hygiene. Evidence report. Available at: http://www.wsscc.org/resources/resource-publications/her-it\%E2\%80\%99s-big-issue-puttingwomen-centre-water-supply-sanitation-and [Retrieved 23 June, 2014].

[103] WCD [World Commission on Dams], 2000. Dams and Development: A New Framework for Decision-making. London: Earthscan. 
[104] Weber, L. and Nkemdirim, L., 1998. Palmer's drought indices revisited. Georafiska Annaler 80A, 153-172.

[105] Weichselgartner, J. and Kelman, I., 2014. Geographies of resilience: Challenges and opportunities of a descriptive concept. Progress in Human Geography 1-19.

[106] Weinthal, E., Vengosh, A., Marei, A., Gutierrez, A. and Kloppmann, W., 2005. The water crisis in the Gaza strip: prospects for resolution. Ground Water 43(5), 653-660.

[107] Welsh, L.W., Endter-Wada, J., Downard, R. and Kettenring, K.M., 2013. Developing adaptive capacity to droughts: the rationality of locality. Ecology and Society 18(2), 7.

[108] WHO [World Health Organization], 2011. Guidelines for drinking-water quality. $4^{\text {th }}$ ed. World Health Organization.

[109] Wilhite, D.A. and Buchanan-Smith, M., 2005. Drought as hazard: understanding the natural and social context. In Wilhite, D.A. (ed.), Drought and water crises: science, technology, and management issues, p. 3-29. Taylor and Francis Group.

[110] Wilhite, D.A. and Glantz, M.H., 1985. Understanding the drought phenomenon: The role of definitions. Water International 10, 111-120.

[111] WMO and GWP [World Meteorological Organization and Global Water Partnership], 2014. National Drought Management Policy Guidelines: A Template for Action (D.A. Wilhite). Integrated Drought Management Programme (IDMP) Tools and Guidelines Series 1. WMO, Geneva, Switzerland and GWP, Stockholm, Sweden.

[112] Wolfe, S. and Brooks, D.B., 2003. Water scarcity: an alternative view and its implications for policy and capacity building. Natural Resources Forum 27, 99-107.

[113] Zeitoun, M., 2008. Power and water in the Middle East: the hidden politics of the PalestinianIsraeli water conflict. London, I.B. Tauris.

[114]Zhang, J., Mauzarall, D.L., Zhu, T., Liang, S., Ezzati, M. and Remais, J.V., 2010. Environmental health in China: progress towards clean air and safe water. Lancet 375, 11101119. 